\title{
Self-Management and Self-Efficacy in Hemodialysis Patients
}

\author{
Agavia Kristi Purba, Etika Emaliyawati, Aat Sriati \\ Faculty of Nursing, Universitas Padjadjaran \\ Email:agaviakristi@gmail.com
}

\begin{abstract}
Introduction, the success of treatment in chronic renal failure patients with hemodialysis required the existence of self-management and self-efficacy. Previous studies showed that self-efficacy had the influence to bring up self-management behavior. The purpose of this study was to determine patients' self-management and selfefficacy in chronic renal failure patients who had hemodialysis at Advent's Hospital Bandung. Methods, this study was a quantitative descriptive research. The study samples were chosen using consecutive sampling technique. The number of samples was 75 patients. Data were collected using the SMBQ and PEPPI+Life Options DeNovo instruments. Data were analyzed using the quantitative descriptive approach with mean value and frequency distribution. The results of self-efficacy in patients with chronic renal failure with hemodialysis was high $(54.7 \%)$ and the self-management behavior was in a good category $(53.3 \%)$. The conclusion of this study is that the patient has a good self-management as well as self-efficacy. However, this study found the poor category of the partnership in caring aspect. Recommendation There is a need for a strategy to improve the self-management in the partnership in caring aspect by providing emotional support, educating patients related to treatment and care, and evaluating patients' health development periodically.
\end{abstract}

Keywords: Chronic renal failure, Hemodialysis, Self-efficacy, Self-management. 
Agavia Kristi Purba : Self-Management and Self-Efficacy in Hemodialysis Patients

\section{Introduction}

Chronic renal failure (CRF) is a progressive and irreversible problem in renal function (Smeltzer \& Bare, 2002). This condition affected other system organs. The data showed that the number of incidence of CRF patients with treatment increased from 2007 to 2014. In 2014, the number of CRF incidence was 17,193 patients with an active patient ratio of 11,689 people (PERNEFRI, 2014). About 5,504 of patients were disobedient to treatments.

One therapy method to treat $\mathrm{CRF}$ is hemodialysis. Data showed that $82 \%$ of CRF patients preferred hemodialysis therapy rather than Continues Ambulatory Peritoneal Dialysis (CAPD) (12.8\%) and kidney transplant (2.6\%) (PERNEFRI, 2014). This finding suggests that hemodialysis is one of the most common therapy to replace impaired renal function in society.

Patients with hemodialysis require optimal treatment management including controlling weight gain between hemodialysis periods, and laboratory values; hemoglobin, urea and creatinine. To achieve the optimal management of treatment, they need a good self-management in order hemodialysis process and to avoid more severe complications. The management includes fluid restriction, nutritional diet, drug management, and exercise (Welch et al., 2014).

CRF patients rely on the hemodialysis treatment along their lifetime. However, if the treatment is managed properly, it would easy for patients in reducing burdens and dependence on others in their daily activities. However, the psychological complications, and social stresses of treatments may appear since the patient has been diagnosed with CRF. The mortality rate is quite high in patients with hemodialysis therapy. Risk factors include age, physical disorders, nutrition, heart failure and depression (Bradbury et al., 2007; Nasution et al., 2013). Hemodialysis would not run effectively without patients' confidence in facing of all lifetime treatment processes.

One effective way to reduce mortality, prevent complications and improve the quality of life in patients with hemodialysis is improving patients' level of self -efficacy (Griva et al., 2011; Nasution et al., 2013). Bandura (1997) stated that self-efficacy is the perception of the ability of individuals to plan and implement actions that lead to the achievement of certain goals. In other words, self-efficacy is a key factor for people to achieve something from what they think, believe, feel, and expect. Self-efficacy is needed in patients with CRF to be able to perform self-management of this incurable disease.

If patients' self-efficacy is good, the selfmanagement performs would be good too. Self-management is patients' involvement in all aspects of chronic illness and its implications, including medical management, changes in social and work roles, and coping (Taylor, 2006). Self-management can be defined as the ability of a person to holistically manage the conditions of illness and changes in lifestyle that must be lived related to chronic pain. Self -management is important in patients living with CRF to prevent deteriorating of disease.

Advent Bandung Hospital is a private hospital that has hemodialysis services. There are 2 rooms in the Hemodialysis ward with 50 the hemodialysis machines. The Hemodialysis ward provides services 6 days a week with 3 periods of hemodialysis schedule which are Sunday \& Wednesday, Monday \& Thursday, and Tuesday \& Friday. The majority of patients have schedules of hemodialysis 2 times a week with 4-5 hours of therapy process a day. At least 50 patients who have their routine schedule are visiting the hemodialysis ward every day. This hospital also provides emergency services for patients with chronic renal failure that require immediate hemodialysis. Currently, there is no similar research has been conducted related to self-efficacy and self-management studies of CRF patients in RS Advent Bandung. This study would have implications for improving the hospital services.

To support the phenomenon of this study, researchers observed 10 patients with CRF in RS Advent Bandung. From the observation, all patients have an active communication with health workers such as doctors and nurses. The majority of patients compliant with eating and drinking as health professionals' 
Agavia Kristi Purba : Self-Management and Self-Efficacy in Hemodialysis Patients

recommendation, but sometimes they break the diet roles occasionally. Some patients had experienced breath shortness, body swelling, and back pain. Patients said they read or seek information related to their illness diligently. They seek information independently, for example information about disease or treatment. In general, patients accepted all the health workers' advice.

The researcher also conducted an interview on Wednesday, March 14, 2017 to the head of the Hemodialysis Installation RS Advent Bandung, he said that the most of patients' complication during hemodialysis is hypotension. The majority of patients had a history of hypertension and diabetes mellitus. He also said that patients obtained health education about hemodialysis when they visited the hospital for the first time. The hospital also provides brochure and other media related to the complications of hemodialysis in the hemodialysis room for patients and families. The aimed of this health education was to increase patients' and family's knowledge of CRF treatment. All patients in the Advent Hospital has been hemodialysis for more than a year, so the relationship between patients and health personnels are established.

It is important to assess the self- efficacy and self- management of patients with $\mathrm{CRF}$ and hemodialysis because there are no primary prevention or effective medicines for this diseases. The researcher is interested to conduct a research to assess "Selfmanagement and self-efficacy in CRF patients with hemodialysis at RS Advent Bandung". researcher obtained the research permission from the supervisor with letter no. 3699/ UN6.L1/KM/2016 and permission from the Adventist Education, Training and Research Section. This descriptive quantitative research was conducted in the Hemodialysis Room of RS Advent Bandung in March April 2017. The population in this study was all patients with CRF with hemodialysis. The sample was chosen using consecutive sampling technique. The sample selected by determining the subject that meets the criteria of study in a certain time (Nursalam, 2003). This study involved 75 patients CRF with hemodialysis. The inclusion criteria include hemodialysis patients who have hemodialysis for more than 6 months. Exclusion criteria were patients who unable to complete this study (drop out), the patient whose condition was not possible to be a respondent because of health problems such as dizziness, pain, decreased consciousness, difficulty speaking, and labile. Samples who involved in this study should state their willingness to follow this research by signing the informed consent, and fill in the questionnaire. The data was collected using the SelfManagement Behavior Questionnaire and Perceived Efficacy in Patient Physician Interactions Questionnaire + Life Options DeNovo compiled by Curtin et al. (2008). These questionnaires had reliability value $\alpha=0.70-0.84$ for self-management and reliability value $\alpha=0.92$ for self- efficacy. Data were analyzed using descriptive statistic and presented in percentage and mean value of all question scores from each dimension.

\section{Research Method}

\section{Research Results}

This data collection was conducted after the This section presents the study findings.

Table 1 Frequency Distribution of Respondents $(n=75)$

\begin{tabular}{|c|c|c|}
\hline Characteristic & f & $\%$ \\
\hline \multicolumn{3}{|l|}{ Age } \\
\hline $18-40$ & 15 & 20.0 \\
\hline $40-60$ & 36 & 48.0 \\
\hline over 60 & 24 & 32.0 \\
\hline \multicolumn{3}{|l|}{ Gender } \\
\hline Man & 42 & 56.0 \\
\hline
\end{tabular}


Agavia Kristi Purba : Self-Management and Self-Efficacy in Hemodialysis Patients

\begin{tabular}{lcc}
\hline Woman & 33 & 44.0 \\
Religion & 54 & 72.0 \\
Muslim & 16 & 21.3 \\
Christian & 4 & 5.3 \\
Catholic & 1 & 1.3 \\
Buddhist & & \\
Education & 7 & 9.3 \\
Elementary & 8 & 10.7 \\
Junior School & 30 & 40.0 \\
Senior School & 12 & 16.0 \\
College & 18 & 24.0 \\
University & & \\
Working Status & 20 & 26.7 \\
Employment & 55 & 73.3 \\
Unemployment & & \\
Period of Hemodialysisi & 53 & 70.7 \\
Less than 5 years & 22 & 29.3 \\
More than 5 years & & \\
Disease History & 6 & 8.0 \\
Diabetes Mellitus & 33 & 44.0 \\
Hypertension & 8 & 10.7 \\
Diabetes Mellitus \& Hypertension & 2 & 2.7 \\
$\begin{array}{l}\text { Diabetes Mellitus and other } \\
\text { diseases }\end{array}$ & 9 & 12.0 \\
Hypertension and other diseases & 4 & 5.3 \\
Diabetes, Hypertension and other \\
deseases \\
$\begin{array}{l}\text { Others (unknow, lupus, polysystic, } \\
\text { uric acid, etc) }\end{array}$ & & 17.3 \\
\hline & & \\
\hline
\end{tabular}

Table 2 Frequency Distribution of Patients' Self-Management $(n=75)$

\begin{tabular}{ccccccc}
\hline \multicolumn{7}{c}{ Self-management } \\
\hline \multicolumn{7}{c}{ Category } \\
\hline $\mathbf{x}^{-}$ & $\boldsymbol{\sigma}$ & \multicolumn{3}{c}{ Good } & & Poor \\
& & f & \% & f & \% \\
\cline { 2 - 7 } & 8.012 & 40 & & 53.3 & 35 & 46.7 \\
\hline 77.41 & & & & & &
\end{tabular}

Table 3 The dimensions of Self-Management $(n=75)$

\begin{tabular}{|c|c|c|c|c|c|}
\hline \multicolumn{6}{|c|}{ Dimension of Self-Management } \\
\hline \multicolumn{6}{|c|}{ Communication with Caregiver } \\
\hline & & \multicolumn{4}{|c|}{ Category } \\
\hline & & \multicolumn{2}{|c|}{ High } & \multicolumn{2}{|c|}{ Low } \\
\hline$x^{-}$ & $\sigma$ & f & $\%$ & $\mathbf{f}$ & $\%$ \\
\hline 13.00 & 3.018 & 49 & 65.3 & 26 & 34.7 \\
\hline
\end{tabular}


Agavia Kristi Purba : Self-Management and Self-Efficacy in Hemodialysis Patients

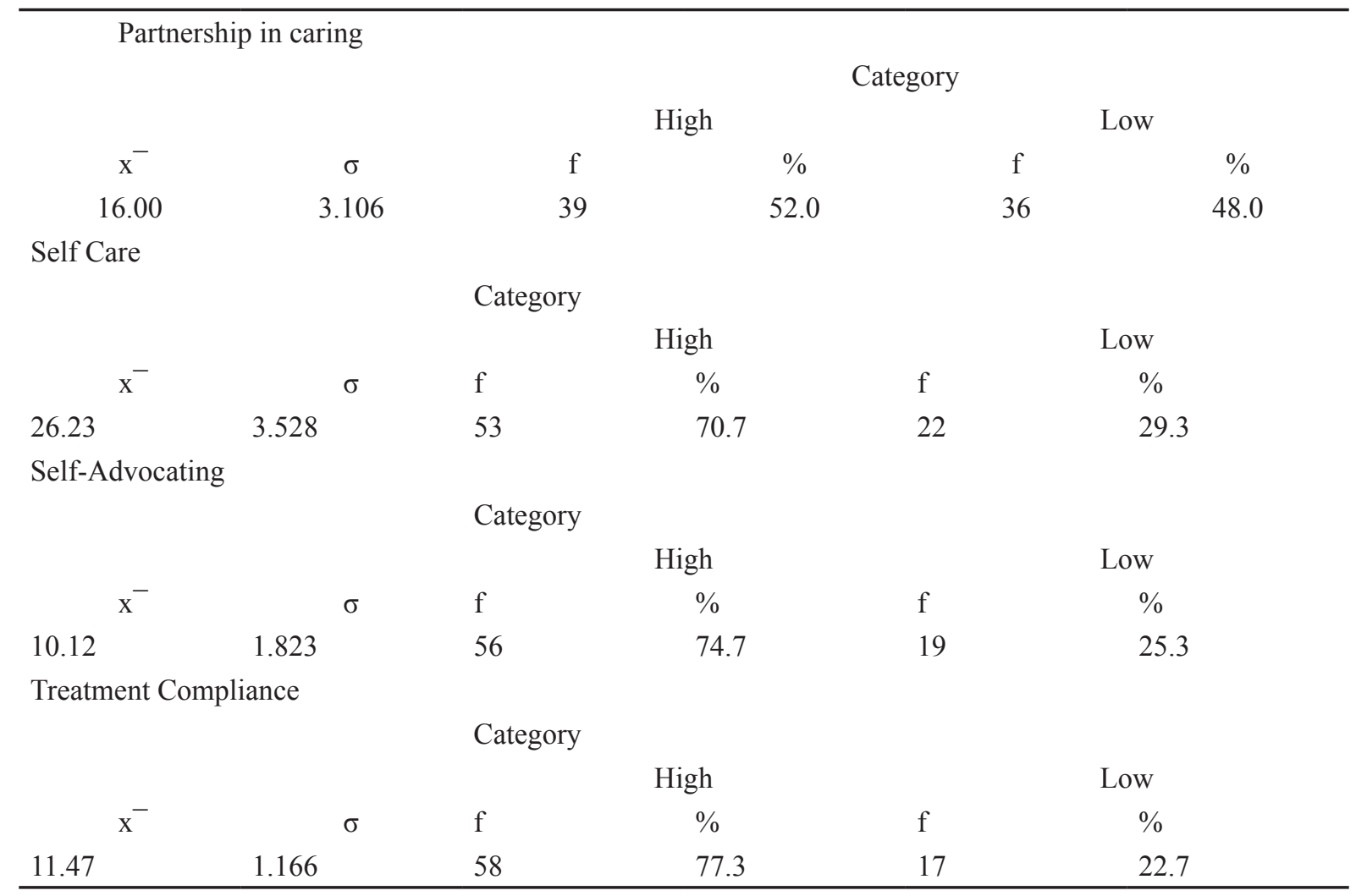

Table 4 Frequency Distribution of Patients' Self-Efficacy $(n=75)$

\begin{tabular}{|c|c|c|c|c|c|}
\hline \multicolumn{6}{|c|}{ Self-efficacy } \\
\hline \multicolumn{6}{|c|}{ Category } \\
\hline \multirow[t]{2}{*}{$\mathbf{x}^{-}$} & \multirow[t]{2}{*}{$\sigma$} & \multicolumn{2}{|c|}{ Good } & \multicolumn{2}{|c|}{ Poor } \\
\hline & & f & $\%$ & f & $\%$ \\
\hline 49.16 & 5.742 & 41 & 54.7 & 34 & 45.3 \\
\hline
\end{tabular}

Table 5 The dimension of Self- Efficacy $(n=75)$

\begin{tabular}{|c|c|c|c|c|c|}
\hline \multicolumn{6}{|c|}{ Dimensions of Self-Efficacy } \\
\hline \multicolumn{6}{|c|}{ Communication with Caregiver } \\
\hline & & \multicolumn{4}{|c|}{ Category } \\
\hline & & \multicolumn{2}{|c|}{ High } & \multicolumn{2}{|c|}{ Low } \\
\hline$x^{-}$ & $\sigma$ & $\mathbf{f}$ & $\%$ & f & $\%$ \\
\hline 21.13 & 3.193 & 50 & 66.7 & 25 & 33.3 \\
\hline \multicolumn{6}{|c|}{ Partnership in caring } \\
\hline & & \multicolumn{4}{|c|}{ Category } \\
\hline & & \multicolumn{2}{|c|}{ High } & \multicolumn{2}{|c|}{ Low } \\
\hline $\mathrm{x}^{-}$ & $\sigma$ & $\mathbf{f}$ & $\%$ & f & $\%$ \\
\hline 28.03 & 3.401 & 44 & 58.7 & 31 & 41.3 \\
\hline
\end{tabular}


Agavia Kristi Purba : Self-Management and Self-Efficacy in Hemodialysis Patients

Table 6 Frequency Distribution of Patients' Self -Management and Self-Efficacy $(n=75)$

\begin{tabular}{cccc}
\hline \multicolumn{4}{c}{ Self-Management } \\
\hline \multirow{2}{*}{ Self- Efficacy } & & Good & Poor \\
& High & $26(34,0 \%)$ & $14(19,0 \%)$ \\
& Low & $14(19,0 \%)$ & $21(28,0 \%)$ \\
\hline
\end{tabular}

Table 1 presents that almost a half of respondents were in the middle age range $(48.0 \%)$. Most of the respondents were male $(56.0 \%)$. The majority of respondents were Muslim (72.0\%). Almost a half of respondents attended Senior high School $(40.0 \%)$. The majority of them were retired from their jobs $(73.3 \%)$.

Table 2 reveals that the majority of respondent have a good self-management $(53.3 \%)$. The following table describes the detail dimensions of self-management.

Table 3 describes that the majority of the respondents had a good category in the medication compliance $(77.3 \%)$.

Table 4 present that the majority of respondents have a good self-efficacy.

\section{Discussion}

Self-Management in Chronic Renal Failure Patients with Hemodialysis at Advent Bandung Hospital

Self-management of CRF patients with hemodialysis include their ability to manage themselves to communicate with health professionals, build a partnership with health workers, self-care, self-advocacy, and adherence to treatments. According to these study findings, patients' selfmanagement mostly in a good category $(53.3 \%)$, however some respondents in the poor category $(46.7 \%)$. This finding in line with a study conducted by Fan et al. (2015). There were respondents in poor category, it may be because of the patient entrusted health workers, friends, and families who have more control to treat patients than themselves. The ability to manage their self may also less because they were not familiar with disease or treatment. Good or poor selfmanagement may influence by internal and external factors.

Communication with care givers is the foundation of the self-management dimension. Patients should be able to report symptoms, problems, good or bad experiences, or concerns related to the treatment. This study found that most of the respondent had good communication with health worker $(65.3 \%)$. While, less than a half of respondents had poor communication with health workers $(34.7 \%)$. Communication is the key relationship between patients and health professionals in order to maintenance treatment process optimally. Communication is characterized by mutual acceptance, mutual trust, and respect each other.

The poor communication between patients and care givers in this study was in line with research conducted by Curtin et al. (2008). There are no active patient roles to initiate communication with health professionals. Therefore, health workers, especially nurses in the hemodialysis room, are expected to establish a good relationship including sharing experiences, giving information, and building trust with each other. A good relationship between patients and care giver is one way to manage a good treatment process and have a positive influence on patients' everyday life.

Partnerships in caring are the second important dimension of self-management behavior. Although patients are more aware of their condition, it is unlikely that the patient can perform activities in illness condition by establishing a cooperative relationship with a secondary source. In this study, the majority of respondents had a good partnership in caring $(52.0 \%)$, while almost half of them had a poor score in this dimension $(48.0 \%)$. Building a good partnership with health workers would help an optimal treatment process. This finding in agreement with Utarini's (2010) study that a good partnership between patients-care givers expresses a sense of satisfaction of services provided, and patients provide feedback to 
Agavia Kristi Purba : Self-Management and Self-Efficacy in Hemodialysis Patients

hospitals' services and facilities that still need improvement. Respondents with poor partnerships in caring, it may because of the lack of independent of their roles related understanding their conditions and illness (eg searching information through books/ internet) and the health information only depend on the health workers information. On the other hand, patients also need to have a good partnership with family or the environment. The family is the "secondary source" after the health worker. This finding in line with Panjaitan et al.'s (2015) study that the role of a family is crucial for every aspect of caring from the planning phase to the rehabilitation phase. Family's support includes emotional support, information, or advice. In this study, one of the support provided by health professionals was information support. The results of a good partnership from patients' side were they felt to be informed, monitored, and adjusted about their illness. Health workers should be able to be a good consultant to help patients with what the patient thinks and feels. The role of health workers in providing support to families and the surrounding environment, and it is expected to help patients to manage their disease properly.

Self-care is a dimension of selfmanagement behavior that partly derived from the patient empowerment approach. The empowerment perspective shows that patients acquired knowledge, skills, and responsibilities of changing actions and effects that would improve their personal health care. This study found that respondents had a good self-care $(70.7 \%)$, and $29.3 \%$ of them had poor self-care. Self-care influences the incidence of complications both intradialysis and post-dialysis. According to characteristics of respondents, male respondents are riskier in developing CRF. This is in agreement with a study conducted by Kazancioglu (2011), he found that CRF patients with hemodialysis are more common in male patients. Clinically, males have a risk of CRF two times greater than females. This is possible, may because women pay more attention to health and maintain a healthy lifestyle than men. This research also in line with Anita and Novitasari (2017), they found that keeping adequate fluid intake in a day is important to avoid complications such as shortness breath, hypertension, and pulmonary edema. Patients are advised to consume no more than $500 \mathrm{~mL}$ of fluid. This study findings in line with Marantika and Devi (2014) that patients encouraged to limit their intake containing potassium, water, and salt. Foods contain potassium such as fruits, vegetables. Limiting salt is useful to prevent thirstily, too much fluid will also cause weight gain. Health workers are expected to continue in monitoring patients' intake, empowering patients who are able to exercise, and monitoring patients' sleep patterns and rest. It is expected that health education from health professional would continue in patients with hemodialysis.

Self-advocacy aimed to empower patient to speak about his or her own needs. Selfadvocacy is a skill that every patient has to communicate effectively, communicate their opinions or ideas, be able to negotiate with health professionals, express their interests, wishes, and expectations, be able to act positively in their own interests and be able to take decisions and take responsibility. In this study, the majority of respondents had a good self-advocacy $(74.7 \%)$, while $25.3 \%$ of them had poor self-advocacy This study is consistent with Asgari et al.'s (2011) study, she stated that the self-advocacy dimension includes receiving support from family and the environment, giving trust to health workers, showing empathy and responsiveness, and satisfying with the outcomes of care and treatment. This is important because receiving support from a good environment such as family, neighborhood, and health professionals would provide a high confidence and reduce the fear of treatment. Self-advocacy is important for patients so they are able to deliver all the needs, abilities, shortcomings, opinions, and expectations related to the treatment.

Some patients had poor advocacy. This may be because of the lack of communication. Therefore, it is expected that health workers can be a good advocate so they can encourage patients to deliver all the needs, abilities, shortcomings, opinions, and expectations related to treatment. The patient must have skills to communicate effectively, to argue, to negotiate, to convey hope for the smoothness 
Agavia Kristi Purba : Self-Management and Self-Efficacy in Hemodialysis Patients

of his treatment.

An effective communication and partnership relationships between patients and care giver are related to compliance of the treatment. The CRF patients with hemodialysis, treatment adherence may be difficult to do. All of them are required to monitor the intake of food, fluids, and medicines. In addition, they also need to have a healthy lifestyle such as avoiding smoking or drinking alcohol, having an ideal weight, and doing exercise. The history of the disease affected medicines consumption. In this study, almost a half of respondents had a history of hypertension (44.0\%). This is in line with Putri et al. (2014) and Pernefri's (2014) studies. Hypertension is the most common etiology in CRF patients with hemodialysis. These study findings are also in line with research Nurjanah's (2012) study which stated that there is a relationship between hypertension with the incidence of CRF. Hypertension damages the blood vessels, so the blood supply to the kidneys decreased. It is possible a person with chronic hypertension have a high risk for kidney failure. This incidence accelerates the disease progression and increases patients' mortality rates (de Pinho et al., 2015). In this study, the majority of respondents had a good medication adherence (77.3\%) while $22.7 \%$ of them had poor medication adherence $(22.7 \%)$. Medication compliance had a very important role in improving CRF patients' quality of life especially who with hemodialysis.

According to Curtin et al.'s (2008) study, patients' adherent to complete treatment and medication was their doctors, they did not take herbal medicines or natural treatments. The majority of patients in this study take hypertensive medications, as they have a history of hypertension. Each patient consumes more than one type of medicines, for example beta blockers and diuretics. This study is in line with Saherna (2017), patients chose herbal remedies because they believed that taking alternative or herbs medicine is safe. On the other hand, these study findings found patients who had hemodialysis schedule every week, they had a history of consuming herbal medicines. Health workers are expected to monitor patients who consuming herbal or alternative inappropriately, it risks for patient's condition.

Self-Efficacy in CRF Patients with Hemodialysis

Self-management is closely related to selfefficacy. The self-management will be good if the person's self-confidence is also high. Selfefficacy in CRF patients with hemodialysis is patients' confidence to communicate with care giver and make partnerships in caring. In this study, self-efficacy was generally in the high category $(54.7 \%)$, but almost half of the respondents were in a low category $(45.3 \%)$. This finding is in agreement with Andini et al.'s (2012) study that some patients were in a low category. This may because of they loss of control and confidence in their life especially related to the future.

In this study, some respondents had high confidence to communicate with care providers $(66.7 \%)$, while $33.3 \%$ of respondents were in a low category. Communication is the main key to patients' confidence to start a conversation with health workers. These findings in line with Balaga's (2012) study that health workers would able to address the patients' needs if they have a good verbal communication. As a result, patients would follow treatments of chronic conditions including diet, and a healthy lifestyle. Similarly, Curtin et al. (2008) also stated the importance of a good communication between patients and health workers.. It is expected that health workers provide support to patients' confidence so they able to express their condition and feelings.

This study found that the majoriy of respondents had high confidence in partnerships in caring (58.7\%). Having a good relationship and cooperation between patients and health professionals required a high self-confidence. This is useful to optimize treatment and patient care. This study is in line with research conducted by Kim et al. (2013), self-belief has a positive impact on medication adherence, effective disease control, and reduce death rates. Behavioral partnerships include searching health information from other sources actively, understanding their own problems and how to solve it, and identifying problems that should report to health professionals. 
Agavia Kristi Purba : Self-Management and Self-Efficacy in Hemodialysis Patients

The high confident of patients in partnership activities very important for their disease treatment and caring processes.

Self-management and Self-efficacy in CRF Patients with Hemodialysis

Self-management and Self-efficacy are related to each other. When the patient had a high self-efficacy, she/he had also a good self-management. The majority of respondents had good self-management and high self-efficacy $(34.0 \%)$. Du and Yuan (2010) revealed that self-efficacy was an important indicator to evaluate selfmanagement. High self-efficacy would result in a good self-management to improve the health status of patients (Bandura, 1989 in Du \& Yuan, 2010). Self-efficacy would be improved health programs including training, support, encouragement, positive personal experiences, and modeling. Self-efficacy is positively related to self-management behavior. Raising self-management would have a long-term benefit for CRF patients with hemodialysis (Curtin et al., 2008).

This study described several respondents had poor self-management and low selfefficacy $(28.0 \%)$. A patient who believed in her ability to manage her own condition is potential to have a good health outcome. Lorig et al. (2006) found that a six-month self-efficacy change would extend health status for 1 year. This is indicated that selfmanagement successfully performed by the patient. However, this study also found the low self-efficacy that resulting in a poor self-management of patients. Patients' selfconfidence in ability to perform tasks and behaviors of his condition was managed successfully and would have a huge impact on their health. Someone with high selfefficacy is more likely would have a good self-management (Sritaparipat et al., 2012).

\section{Conclusion}

This study results found that the majority CRF patients with hemodialysis at RS Advent Bandung had good self-management, and the rest had low self-management. For the level of self-efficacy, the majority of respondent had high self-efficacy and a small number of respondents had low self-efficacy.
This research is expected to be the preliminary data and provide information related to patient behavior towards selfmanagement and self-efficacy. The nurses need to motivate patients during the hemodialysis process, then patients' selfmanagement would be good and patients have high self-efficacy. Nurses actions including providing emotional and psychological support to increase patients' self-confidence, helping patients in self-managing related to the treatment process, and increasing the intensity of health education at least once every month. The health education includes information about disease and treatment, complications and side effects. Facilitating patients and family with accessible brochures, and evaluating patient's health status everyday related to hemodialysis, adhere to interventions, diet at home, activities patterns, rest patterns, medication patterns, physical and psychological patients.

The hospital is expected to establish a program that gives the opportunity to patients of an active interaction with hospital management in providing a positive feedback for successful hemodialysis intervention. This can be one solution to improve selfmanagement and self-efficacy of CRF patients with hemodialysis.

Researchers

These study findings provide a preliminary information about self-management and selfefficacy in CRF patients with hemodialysis. For the future research, it is expected to develop an instrument that applicable and more accurate for a wide population.

\section{References}

Andini, I.S., Agustin, W.R., \& Kurniawan, S.T. (2014). Hubungan self-efficacy dengan kualitas hidup pasien gagal ginjal kronik yang menjalani terapi hemodialisa di RSUD Sukoharjo. Jurnal STIKes Kusuma Husada Surakarta. Accessed from http://digilib. stikeskusumahusada.ac.id/files/disk1/33/01gdl-intansaria-1622-1-artikel-0.pdf on 15 June 2017 on 3:07 PM.

Anita, D.C., \& Novitasari, D. (2017). Kepatuhan pembatasan asupan cairan 
Agavia Kristi Purba : Self-Management and Self-Efficacy in Hemodialysis Patients

terhadap lama menjalani hemodialisa. Jurnal Ilmu Keperawatan Universitas Aisyiyah Yogyakarta, 104-112. Accessed from http:// jurnal.unimus.ac.id/index.php/psn12012010/ article/view/2280/2261 on 20 May 2017 on 7:41 PM

Asgari, M.E., Khoshknab, F., \& Tamadon. (2011). The perception of chronic renal failure patients from advocacy resources in adjusment with hemodialysis: A qualitative study. Iranian Journal of Critical Care Nursing, 4(3), 133-144. Accessed from http://www.inhc.ir/article-A-10-221-1-1-en. html on 24 May 2017 on 5:22 PM.

Balaga, P.A.G. (2012). Self-efficacy and self care management outcome of chronic renal failure patients. Asian Journal of Health. International Peer Reviewed Journal, 2, 111-129. ISSN: 2094-9243. doi: http:// dx.doi.org/10.7828/ajoh.v.2i1.121. Access from https://submissions.scholasticahq.com/ api/v1/attachments/470/download on 26 May 2017 on 9:13 AM.

Curtin, R.B., Walters, B.A.J., Schatell, D., Pennel, P., Wise, M., \& Klicko, K. (2008). Self-efficacy and self-management behaviors in patients with chronic kidney disease. National Kidney Foundation. Medical Education Institute Inc: University of Miami, Madison, 15(2), 191-205. Accessed from http://www.ackdjournal.org/article/S15485595(08)00007-4/pdf.

de Pinho, N.A., da Silva, G.V., \& Pierin, A.M.G. (2015). Prevalence and factors associated with chronic kidney disease among hospitalized patients in A University Hospital in The City of Sao Paulo, Brazil. Jornal Brasileiro de Nefrologia, 37(1). Access from http://www.scielo.br/scielo.php?pid=S0101$28002015000100091 \& \mathrm{script}=\mathrm{sci}$ arttext\&tlng=en on 2 June 2017 on 11:45 AM.

Du, S., \& Yuan, C. (2010). Evaluation of patient self-management outcomes in health care: A systematic review. International Nurs Rev., 57(2), 159-67. DOI:10.1111/j.14667657.2009.00794.x. Access from https:// www.ncbi.nlm.nih.gov/pubmed/20579149 on 13 July 2017 on 9:42 AM.

Fan, J.L., Kong, Y., Shi, S.H., \& Cheng, Y.H. (2016). Positive correlations between the health locus of control and self-management behaviours in hemodialysis patients in Xiamen. International Journal of Nursing Sciences, 3(1), 96-101. Access from http:// www.sciencedirect.com/science/article/pii/ S2352013215300259 on 15 June 2017 on 3:27 PM.

Kazancioglu, R. (2011). Risk factors for chronic kidney disease: an update. kidney international supplements. PMCID: PMC4089662, 3(4), 368-371. DOI : 10.1038/kisup.2013.79. Accessed from https://www.ncbi.nlm.nih.gov/pmc/articles/ PMC4089662/ on 2 Juni 2017 on 11:36 AM.

Kim, J.Y., Kim, B., Park, K.S., Choi, J.Y., Seou, J.J., Park, S.H., Kim, C.D., \& Kim, Y.L. (2013). Health related quality of life with KDQOL-36 and its association with self-efficacy and treatment satisfaction in Korean dialysis patients. Qual Life Res., 22, 753-758. DOI 10.1007/s11136-012-0203-x. Accessed from https://link.springer.com/ article/10.1007/s11136-012-0203-x on 21 May 2017 on 8:27 PM.

Lorig, K., Stewart, A., Ritter, P., Gonzalez, V., Laurent, D., \& Lynch. (1996). Outcome measures for health education and other health care interventions. Thousand Oaks CA: Sage Publications, 1996, pp.24-25, 4145. Diakses melalui http://patienteducation. stanford.edu/research/secd32.html pada tanggal 13 Juli 2017 pukul 7:43 AM.

Nasution, T.H., Ropi, H., \& Sitorus, R.E. (2013). Faktor-faktor yang berhubungan dengan manajemen diri pada pasien ynag menjalani hemodialisis di Ruang Hemodialisis RSUP DR Hasan Sadikin Bandung. Jurnal Ilmu Keperawatan, 1(2). Accessed from http://jik.ub.ac.id/index.php/ jik/article/download/26/45 on 20 October 2016 on 2:43 PM.

Nurjanah, A. (2012). Hubungan antara lama hipertensi dengan angka kejadian gagal 
Agavia Kristi Purba : Self-Management and Self-Efficacy in Hemodialysis Patients

ginjal terminal di RSUD dr Moewardi Surakarta. Naskah Publikasi Universitas Muhammadiyah Surakarta. Accessed from http://eprints.ums.ac.id/23959/10/ NASKAH PUBLIKASI.pdf on 20 May 2017 on $8: \overline{1} 9$ AM.

Panjaitan, E.M., Siregar, M.A., \& Sudaryati, E. (2015). Gambaran kepatuhan diet dan dukungan keluarga pada penderita gagal ginjal kronik yang menjalani hemodialisa di Rawat Jalan RSU Haji Medan Tahun 2014. Jurnal Universitas Sumatera Utara, 1(2). Accessed from http://jurnal.usu.ac.id/index. php/gkre/article/view/10038/4552 on 20 May 2017 on 9:06 AM.

PERNEFRI. (2014). Access from http:// www.indonesianrenalregistry.org/ data/INDONESIAN\%20RENAL\% 20 REGISTRY\%202014.pdf on 26 November 2016 on 12:16 PM.

Saherna, J. (2017). Analisis faktor hubungan pemilihan konsumsi obat herbal pada pasien hemodialisa lebih dari tiga bulan terhadap peningkatan ureum dan kreatinin di Rumah Sakit. Fakultas Ilmu Keperawatan Universitas Muhammadiyah Banjarmasin. Caring Nursing Journal, 1(1), 40-48. Accessed from https://journal.umbjm.ac.id/ index.php/caring-nursing/article/view/1/8 on 21 May 2017 on 8:04 PM.

Smeltzer, S.C., \& Bare, B.G. (2002). Buku ajar keperawatan medikal bedah Brunner dan Suddart (Edisi 8 Volume 1). Jakarta: EGC.

Sritarapipat, P., Pothiban, L., Panuthai, S., Lumlertgul, D., \& Nanasilp, P. (2012) . Causal model of elderly thais' self-management behaviours of pre-dialysis chronic kidney disease. Accessed from https://www. tci-thaijo.org/index.php/PRIJNR/article/ viewFile/5566/4840 on 12 July 2017 on 4:21 PM.

Taylor, S.G., \& Renpenning, K. (2011). Self care science, nursing theory and evidence based practice. New York: Spinger Publishing Company.

Utarini, A. (2010). Pasien dan masyarakat sebagai mitra menuju RS berstandar internasional. Universitas Gajah Mada Yogyakarta. Accessed from http://www. mutupelayanankesehatan.net/images/ artikel/Pasien $\% 20$ dan $\% 20$ Masyarakat $\% 20$ dalam $\% 20$ Program $\% 20$ Keselamatan $\% 20$ Pasien\%20_Adi\%20Utarini_2.pdf on 20 May 2017 on 8:51 AM.

Welch, J.L., Johnson, M., Zimmerman, L., Russell, C.L., Perkins, S.M., \& Decker, B.S. (2015). Self-management interventions in stages 1-4 chronic kidney disease: An integrative review. West J Nurs Res., 37(5), 652-678. Accessed from https://www.ncbi. nlm.nih.gov/pmc/articles/PMC4364922/ on 22 January 2017 on 11:18 PM. 